\title{
Provenance Studies of the Ballast Stones found in the North Bay of Tel Dor, Israel
}

\author{
Amanda Holdeman \\ University of Haifa, email: amanda.j.holdeman@gmail.com
}

\begin{abstract}
An ancient trade ship's stability was influenced by presence of ballast stones, loaded and unloaded varying with cargo densities. The result of this variability is an ancient harbour's collection of discarded and saved ballast stones, with origins reflecting a ship's route. Both Fourier Transform Infrared Spectroscopy (FTIR) and thinsection petrography were used jointly on ballast stones collected from the North Bay of Tel Dor, Israel, to identify their origins. This is a new approach to study geological artifacts.. With proposed origins of non-local ballast stones, further assertions of seafaring interactions between Tel Dor and surrounding regions can be made.
\end{abstract}

\section{Key words}

Petrography, Fourier Transform Infrared Spectroscopy, Ballast Stones, Levant Coast, Trade Routes

\section{Introduction}

Tel Dor has been an invaluable source of ancient finds due to its status as a heavily active maritime centre in the eastern Mediterranean with this status spanning many periods (Raban, 1995; Arkin-Shalev, 2015). The ancient tel is located with a view of the open sea and is composed of four natural bays, a rare occurrence along the Levantine coast. Of these bays, the North Bay of Tel Dor seems to offer the most shelter, making it an ideal location for long term and intensive usage and is therefore the subject of high interest to archaeologists exploring the connectivity of the eastern Mediterranean region as a whole. 
Departing from the tracing of foreign material culture intended for trade purposes, this study investigates materials left by ships that came to the harbour with these foreign imports, specifically ballast stones utilised on ancient seafaring vessels. In locations of high cargo traffic, where goods were loaded or unloaded, there will inevitably be ballast stones that were either discarded or supplied to these trade ships accordingly.

This study on the composition of geological artifacts used Fourier Transform Infrared (FTIR) spectroscopy and petrography in tandem, FTIR being selected due to its ease of use in regards to sample testing and its relative newness to the arsenal of laboratory methods utilised in the world of archaeology (Weiner, 2010:71), while petrography was selected because of the extensive information of a speciman it can reveal and its tried-and-true history in geological studies. By examining the compositions of the ballast stones found in the North Bay of Tel Dor and assigning provenience to the stones, ancient voyage routes can be inferred based on where they were collected and loaded onto trade vessels. By reconstructing voyage routes, the significance of Tel Dor's harbour to the inter-connectivity network of the eastern Mediterranean can be examined with more depth. Not only will these ballast stones be a rich source of information of this specific harbour's trade network, but they can also add to the larger base of knowledge of ancient ballasting practices and harbour functions overall, as previous ballast studies have focused on examples associated with shipwrecks and not on discarded piles within an ancient harbour.

In order to fully understand the scope of the ballast stones collected at Tel Dor and the research methods utilised to achieve this goal, the following questions were posed in this study:

What is the provenience of the ballast stones?

What does the provenience of the ballast stones reveal about the maritime routes leading to Dor?

Can the characteristics of the ballast stones indicate any information on ancient ballasting practices?

How can FTIR spectroscopy be integrated with petrography in order to execute geological studies?

\section{Ballast Stones}

\section{Ballast Purpose}

Ballast stones were used in ancient times as a way to improve stability of a ship during its voyage. Instability of a ship is dependent upon the vertical distance between the metacentre and the centre of mass of a loaded ship. If the centre of mass is below the metacentre, this will allow the ship to right herself up to a certain angle of the heel. The addition of ballast will allow the ship's centre of mass to be lowered to remedy any tilting thus making the ship more seaworthy (Fig. 1) (McGrail, 1989: 354-357). When loading cargo onto a ship, ballast was placed on top of soft materials, known as dunnage, in order to prevent damage to the ship herself and the precious cargo. Once the ship was loaded, additional ballast was added according to the weight needs of that particular shipment to ensure a safe voyage (Gorzalczany, 2006: 67). As the voyage of a ship progressed and cargo of varying weight and densities was taken on and off board, ballast stones were accordingly added or removed at each port. Due to these practices, it would stand to reason that each port would contain a heterogeneous assembly of ballast stones reflecting the ship's route.

\section{Selecting Ballast}


According to inscriptions dated to $210 \mathrm{BC}$, there was a corporation of saburraii, or ballastmen, who were specialists working in ports with knowledge of specific practices in regards to acquiring ballast for arriving and departing trade ships (Casson, 1995: 370). The ballast stones collected could come from a number of sources. Stones loaded on to ships at a specific port tended to be of a local nature as these would have been the most readily available. However, in areas of particularly high traffic, the ballastmen would have kept and reused ballast coming off of foreign vessels, resulting in designated piles of "good ballast" within the port that would have been heterogeneous in origin (Gifford, 2008: 40-41). These ballastmen and their subsequent ballast piles were vital in the maintenance of a high traffic port, as unsystematic unloading could cause shallowing of a previously functional harbour (Nantet, 2008: 518-519). In order to fulfill the task of supplying ballast to outgoing vessels, the ballastmen would have had specific criteria in selecting stones for use as mobile ballast, versus stones that would have remained on the vessel as permanent ballast to provide the ship with a minimum level of stability (Lamb, 1988: 5-6). Smaller (hand held), river-worn stones with sufficient density were selected because they could remain relatively stable during voyage so as to not ruin the balance of the ship or inadvertently damage the hull and cargo during transport.

\section{Tel Dor}

Tel Dor is located along the northern coast of Israel, with a view of the open sea, and is composed of four natural bays - a rarity along the very straight Levantine coast, as can be seen on the map (Fig.2). This allowed Dor to establish a longstanding relationship of the town to maritime connectivity with the entire eastern Mediterranean. Of these bays, the North Bay of Tel Dor seems to offer the most shelter, making it an ideal location for long term and intensive usage during ancient times (Raban, 1995; Shalev, 2015) and is therefore the subject of high interest to archaeologists exploring the connectivity of the eastern Mediterranean region as a whole.

\section{Tel Dor North Bay Elements}

Though this study focuses on ballast presence as a by-product of a high traffic harbour instead of ballast associated with a shipwreck, dating the deposition of the ballast stones is difficult. In order to understand these ballast piles in the context of the harbour, we must look at how and when the area itself was used.

Early underwater surveys found large quantities of pottery and stone anchors from the Persian and Hellenistic periods, with some broken parts dating to the Roman and Byzantine periods as well, suggesting maritime activity throughout all four.

The North Bay has a high concentration of harbour installations, especially in the southern part of the bay, indicating intense seafaring and trade activities in this area. There are about a dozen marble columns (Fig. 3), theorized by Raban to be a pergola or medieval jetty made of about a dozen various sized and spaced Roman marble column drums (Raban, 1995: 289). They were originally thought to be a quay, but recent studies have interpreted them as part of a loading site associated with the shipping of tel remains (Shalev, 2015: 152-153).

There are also three washing channels built, it is assumed, to prevent sand from entering the bay and to maintain depth for the bay's functionality. Each of these three channels was used during a different time period and 
corresponds to a different sea level of the Mediterranean, with the latest being quarried after the Byzantine period (Fig. 3) (Raban, 1995: 291-296).

The main structure of this area is rectangular complex (Fig. 3) that was dated to the Roman period and stood until the Byzantine period and has been interpreted as a public storage space as well as a side boundary to an inner harbour for small freighters and fishing boats (Raban, 1995: 289-295).

\section{Materials and Methods}

\section{Materials}

The main difficulty in the collection of ballast materials from this harbour setting is distinguishing between ballast and naturally deposited stones, as well as between construction materials that fell into the harbour's waters and those that had been used as ballast. Four main criteria were used in selecting samples for this study. In regards to shape, prior to this study it was theorized that stream-worn stones (Fig. 4) were preferred for ballast because the lack of sharp edges reduced the chance of damage to the hull of the ship or the cargo she carried (Lamb, 1988: 5). Since it has been assumed the ballast stones within the piles found at Tel Dor's North Bay are mobile ballast (Lamb, 1988: 6), this study focused on hand-sized stones of weights conducive to being handled by a single person. These criteria allow for the inclusion of samples that were used as ballast as a secondary purpose, specifically discarded stone cargo, like architectural components like floor or roof tiling (Fig. 5). Lastly, due to the abundance of kurkar, a specific type of beach rock in the area, this would have been the most quarried stone of the harbour and the kind most commonly used in ballasting ships leaving Dor. Working under this assumption, any stone that did not appear to be kurkar would be deemed non-local and could give evidence of trade routes to Dor. The sampling is therefore purposefully skewed to target possible non-local ballast. Despite this, some samples collected for this study did end up being kurkar due to misidentification during collection. A total of 37 samples was collected from six different underwater and coastal sites within the southern harbour (Fig. 6)

\section{Field Methods: The underwater samples}

The underwater samples were collected from an identified ballast pile that is associated with large hewn stones previously found in the 2013 underwater survey of the North Bay (Yasur-Landau and Arkin, 2013: 27-28). The underwater ballast of Dor North Bay was collected on three different occasions. During the first week of February in 2015, the ballast pile surrounding hewn stones was visited and nine samples were collected underwater. In November 2015, seven more samples were collected from this area. Finally, in February 2016, eight samples surrounding a line of hewn stones identified at a later survey of the North Bay were collected underwater.

\section{Field methods: The coastal stones}

In December 2014, a ballast stone was found in between two hewn architectural blocks at the approximate shoreline. In February 2016, a ballast pile was also identified on the coast and eleven samples were collected. The nature of the pile and extent of the pile containing stones of non-local appearance and show shape and size consistent with ballast stones. The eleven stones were chosen for their non-local appearance, but also as an 
attempt to capture the different types of rock features based on macroscopic and exterior characteristics in the field. Photos were taken of the samples in situ, each specimen was given a basket number, and the GPS point corresponding to the collection place was noted as the stones were collected.

\section{Laboratory Analyses}

Macroscopic analysis

Specific measurements of the samples were recorded and the general shapes of the stones classified using Stoops' chart of sphericity and roundness (Stroops, 2003: 52, fig. 4.14), and the interior colors classified using Munsell's soil color chart (Munsell Color, 2000). For texture classification the stones were broken to reveal interior appearance and their macroscopic textures recorded. Once the interior was exposed, variabilities in texture, color, or other elements of appearance were recorded (Fig. 7).

\section{Fourier Transform Infrared Spectroscopy (FTIR spectroscopy)}

FTIR spectroscopy is a valuable tool in characterising inorganic materials based on the molecular structure of minerals (Weiner, 2010: 91). The technique of FTIR spectroscopy employs shining light beams of multiple wavelengths at a sample and measuring the absorption of each wavelength by the sample. Elevated absorption of light for each wavelength is shown as 'peaks' in the spectra produced. Specific peak values and sets of peaks are characteristic of different minerals (Fig. 8). This method sets itself apart from X-ray diffraction in that it is able to identify both crystalline and amorphous minerals, both of which are expected when looking at geological and archaeological samples.

\section{Petrographic Analysis}

Petrography is one of the most widely used and relied-upon methods for mineral and rock classification. By visually identifying mineral composition as well as characteristics of appearance, rock formation history can be inferred, thus providing a clue to the origin of the stone. For this study, photos were collected of each sample to create an overall picture of the sample's characteristics, including the overall nature of the sample and closeups of details distinguishing the rock type (Fig. 9). The combination of the previously described FTIR spectroscopy and rock petrography is therefore complementary and allows for the most accurate and quick determination of rock type. The sample AH-1 shown in Figures 7-9 was determined to be kurkar beachrock that is local to the Tel Dor coast.

\section{Provenience Studies}

Following the rock type classification and mineral identification from macroscopic, spectroscopy, and petrographic analyses, possible origins of the specimens could be postulated. Geological maps of the eastern Mediterranean coasts and their respective rock types were consulted to find possible sources of the ballast found at Tel Dor (Table 1). Assuming that the outcrops recorded during modern times are consistent with those exposed in ancient times when Tel Dor was an active harbour, outcrops found along the southern (Israeli) and northern (Syrian) Levantine coast, as well as in Cyprus and Turkey, describe possible sources of the foreign ballast stones found within the Northern Bay. 


\section{Origins}

Rock types examined in this study include sedimentary rocks, here in white, totaling to 20 specimens, igneous rocks in light grey, totaling four specimens, and metamorphic rocks in dark grey, totaling to 13 specimens. To summarize, the assemblage of rocks used for this study reflects a mixture of both local and foreign rocks. Of the 37 samples, at least 17 samples might be of local origin, while the other 20 are more likely to have been from foreign sources. Most rocks could not be traced to specific geographic origins, but those that could be traced include the chalks, the igneous, and the metamorphic rocks. These non-local stones are hypothesized to be from Egypt, Syria, Turkey, Cyprus, and certain Aegean Islands (Table 2).

\section{Conclusion}

Despite the inability to determine the precise origins of the ballast stones found in the North Bay of Tel Dor, this study's identification of rock types and specific lithologies allows for general conclusions regarding the stones' origins. These multiple origins of the ballast found and studied support Tel Dor's role as an integral part of the maritime network of the eastern Mediterranean. Characteristics of the stones also reveal information regarding ballasting practice and ancient harbour operations. Prior to this study, ballast stone piles were investigated as a part of individual shipwrecks, whereas this research was able to examine ballast stone samples that theoretically came from many seafaring vessels, thus allowing for both a wider and more in-depth perspective on ballasting practices of the time. This study is one of the few conducted to date to have integrated FTIR spectroscopy with petrographic analysis for material studies, specifically geological material. Because rocks are identified based on mineralogical composition, FTIR offers the advantage of both a rapid analysis of samples and the identification of both crystalline and non-crystalline minerals. By combining these methods this study was able to provide a full picture on rock type of each ballast stone collected.

\section{Acknowledgements}

Thank you to my advisors, Drs. Ruty Shahack-Gross and Assaf Yasur-Landau, as well as the directors, staff, and volunteers with the underwater excavations of the Tel Dor Project. Additional thanks to the Department of Maritime Civilizations at the University of Haifa, the Leon Charney of Marine Sciences, the Sir Maurice and Lady Irene Hatter Foundation.

\section{Work Cited}

Al-Riyami, K., Robertson, A., Dixon, J., and Xenophontos, C., 2002, Origin and Emplacement of the Late Cretaceous Baer-Bassit Ophiolit and its Metamorphic Sole in NW Syria. Lithos 65, 225-260.

Beydoun, Z., 1977, The Levantine Countries: The Geology of Syria and Lebanon (Maritime Regions), in A.E.M. Nairn, W.H. Kanes and F.G. Stehli (eds), The Ocean Basins and Margins, 319-353. Boston: Springer.

Bozkurt, E. and Oberhänsli, R., 2001, Menderes Massif (Western Turkey): Structural, Metamorphic, and Magmatic Evolution-A Synthesis. International Journal of Earth Sciences 89.4, 679-708. 
Bragin, N.Yu. et al, 2005, Sedimentary Rocks of the Mamonia Complex, in V.A. Krasheninnikov and J.K. Hall (eds), Geological Framework of the Levant (Volume 1), 55-69. Historical Production Law.

Brew, G. et al, 2001, Tectonic and Geologic Evolution of Syria. GeoArabia 6.4, 573-618.

Brinkmann, R., 1976, Geology of Turkey. Amsterdam: Elsevier.

Casson, L., 1995, Ships and Seamanship in the Ancient World. Baltimore: Johns Hopkins University Press.

Chan, H., 2004, Igneous and Metamorphic Rocks from SW Cyprus and NW Syria: Evidence for Cretaceous Microplate Collision and Subsequent Tectonic Events in the Eastern Mediterranean. Unpublished Master Thesis. University of Hong Kong.

Ertek, T.A. et al, 2008, The Formation of Beachrock on the North Cyprus Coast. Black Sea/Mediterranean Environment 14, 117-128.

Frechen, M. et al, 2004, Chronology of Pleistocene sedimentary cycles in the Carmel Coastal Plain of Israel. Quaternary International 121, 41-52.

Geological Survey Department of Cyprus, 1979, Geological Map of Cyprus. Map. 1: 250,000 km.

Geological Survey Department of Cyprus, 2017, Geology of Cyprus. Retrieved from http://www.moa.gov.cy/moa/gsd/gsd.nsf/dmlSediments_en/dmlSediments_en?OpenDocument.

General Directorate of Mineral Research and Exploration, 1989, Geological Map of Turkey. Map. 1:2,000,000 km. Ankara.

Gifford, M.J., 2008, Everything is Ballast: An Examination of Ballast Related Prectices to Ballast Stones from the Emanuel Point Shipwrecks. Unpublished Master Thesis. University of Western Florida.

Gorzalczany, A., 2006, Petrographic Analysis of Two Ballast Stones from Tel Mikhal (Tel Michael). Antiqot 52, 67-69.

Gvirtzman, Z., 2010, Gradual uplift and Exposure of North Arabia and Enhanced Sedimentation in the Levant Basin During Neo-Tethys Closure. Jerusalem: Geological Survey of Israel.

Hirsch, F., 2005, The Late Pliocene to Quarternary of Israel, in V.A. Krasheninnikov and J.K. Hall (eds), Geological Framework of the Levant (Volume 2), 489-515. Historical Production Law.

Holdeman, A., 2017, Provenance Studies of the Ballast Stones found in the North Bay of Tel Dor, Israel. Unpublished Master Thesis. University of Haifa.

Krasheninnikov, V.A., 2005a, Cretaceous, in V.A. Krasheninnikov and J.K. Hall (eds), Geological Framework of the Levant (Volume 1), 237-299. Historical Production Law

Krasheninnikov, V.A., 2005b, Neogene, in V.A. Krasheninnikov and J.K. Hall (eds), Geological Framework of the Levant (Volume 1), 343-392. Historical Production Law.

Krasheninnikov, V.A., 2005c, Quarternary, in V.A. Krasheninnikov and J.K. Hall (eds), Geological Framework of the Levant (Volume 1), 393-421. Historical Production Law 
Krasheninnikov, V.A. and Kaleda, K.G., 2005, Stratigraphy and Lithology of the Neoautochthon, in V.A. Krasheninnikov and J.K. Hall (eds), Geological Framework of the Levant (Volume 1), 101-127. Historical Production Law.

Lamb, W., 1988, The Provenance of the Stone Ballast from the Molasses Reef Wreck. Unpublished Master Thesis. Texas A\&M University.

Ma, S.-K. et al., 2011, Early Cretaceous volcanism of the Coastal Ranges, NW Syria: Magma Genesis and Regional Dynamics. Lithos 126, 290-306.

McCay, G.A. and Robertson, A.H.F., 2012, Upper Miocene-Pleistocene Deformation of the Girne (Kyrenia) Range and Dar Dere (Ovgos) Lineaments, Northern Cyprus: Role in Collision and Tectonic Escape in the Easternmost Mediterranean Region. Geological Society 372, 421-445.

McGrail, S., 1989, The Shipment of Traded Goods and of Ballast in Antiquity. Oxford Journal of Archaeology 8. 3, 353-358.

Ministry of Petroleum and Mineral Resources, 1986, Geological Map of Syria. Map. 1:1,000,000 km. Syria Arab Republic: Ministry of Petroleum and Mineral Resources.

Munsell Color, 2000, Munsell Soil Color Chart. New Windsor, N.Y.: Gretag Macbeth.

Nantet, E., 2008, Les activités de lestage dans le monde antique: l'exemple de la corporation des lesteurs á Ostie (2e moitié du le siècle ap. J.-C.-début du IIIe siècle ap. J.-C.), in J. Napoli (ed.), Ressources et activités maritimes des peoples de l'Antiquité, 515-521. Boulogne-sur-Mer: Centre de Recherche en Histoire Atlantique et Littorale. Pinar-Erdem, N., 1974, The Turkish Green Rocks. Bulletin of Mineral Resource Exploration Institution of Turkey 8, 119-131.

Portnyagin, M.V., 2005, The Dyke Complex, in V.A. Krasheninnikov and J.K. Hall (eds), Geological Framework of the Levant (Volume 1), 21-25. Historical Production Law.

Raban, A., 1995, Dor-Yam: Maritime and Coastal Installations at Dor in their Geomorphological and Stratigraphic Context, in E. Stern (ed.), Excavations at Dor, Final Report. Volume I A. Areas A and C: Introduction and Stratigraphy, 285-354. Jerusalem: Institute of Archaeology of the Hebrew University and the Israel Exploration Society.

Rosenfeld, A. and Hirsch, F., 2005, The Cretaceous of Israel, in V.A. Krasheninnikov and J.K. Hall (eds), Geological Framework of the Levant (Volume 2), 393-459. Historical Production Law.

Shalev, E.A, 2015, The North Bay of Dor: A Roman Seafront and Byzantine Anchorage. Unpublished Master Thesis. University of Haifa.

Silantyev, S.A. and Krasheninnikov, V.A., 2005, The Troodos Ophiolite Complex, in V.A. Krasheninnikov and J.K. Hall (eds), Geological Framework of the Levant (Volume 1), 7-21. Historical Production Law.

Silantyev, S.A. et al, 2005, The Sedimentary Cover of the Troodos Massif, in V.A. Krasheninnikov and J.K. Hall (eds), Geological Framework of the Levant (Volume 1), 41-55. Historical Production Law.

Silantyev, S.A., 2005a, The Plutonic Complex, in V.A. Krasheninnikov and J.K.Hall (eds), Geological Framework of the Levant (Volume 1), 25-35. Historical Production Law. 
Silantyev, S.A., 2005b, Amphibolites and Metasediments from Tectonic Blocks within the Serpentinite Melange, in V.A. Krasheninnikov and J.K. Hall (eds), Geological Framework of the Levant (Volume 1), 70101. Historical Production Law.

Singer, A., 1967, The Argillation of Sub-Marine Tuffs from the Mount Carmel, Israel. Clay Minerals 7, 101110.

Weiner, S., 2010, Microarchaeology: Beyond the Visible Archaeological Record. Cambridge: Cambridge University Press.

Yasur-Landau, A. and Arkin, E., 2013, Survey in the North Bay, in A.Yasur-Landau and E. Arkin (eds), Underwater Survey of Tel Dor, Survey File S-389/2012, 17-36. Haifa: The Recanti Institute of Maritime Studies and University of Haifa.

\section{Figures}

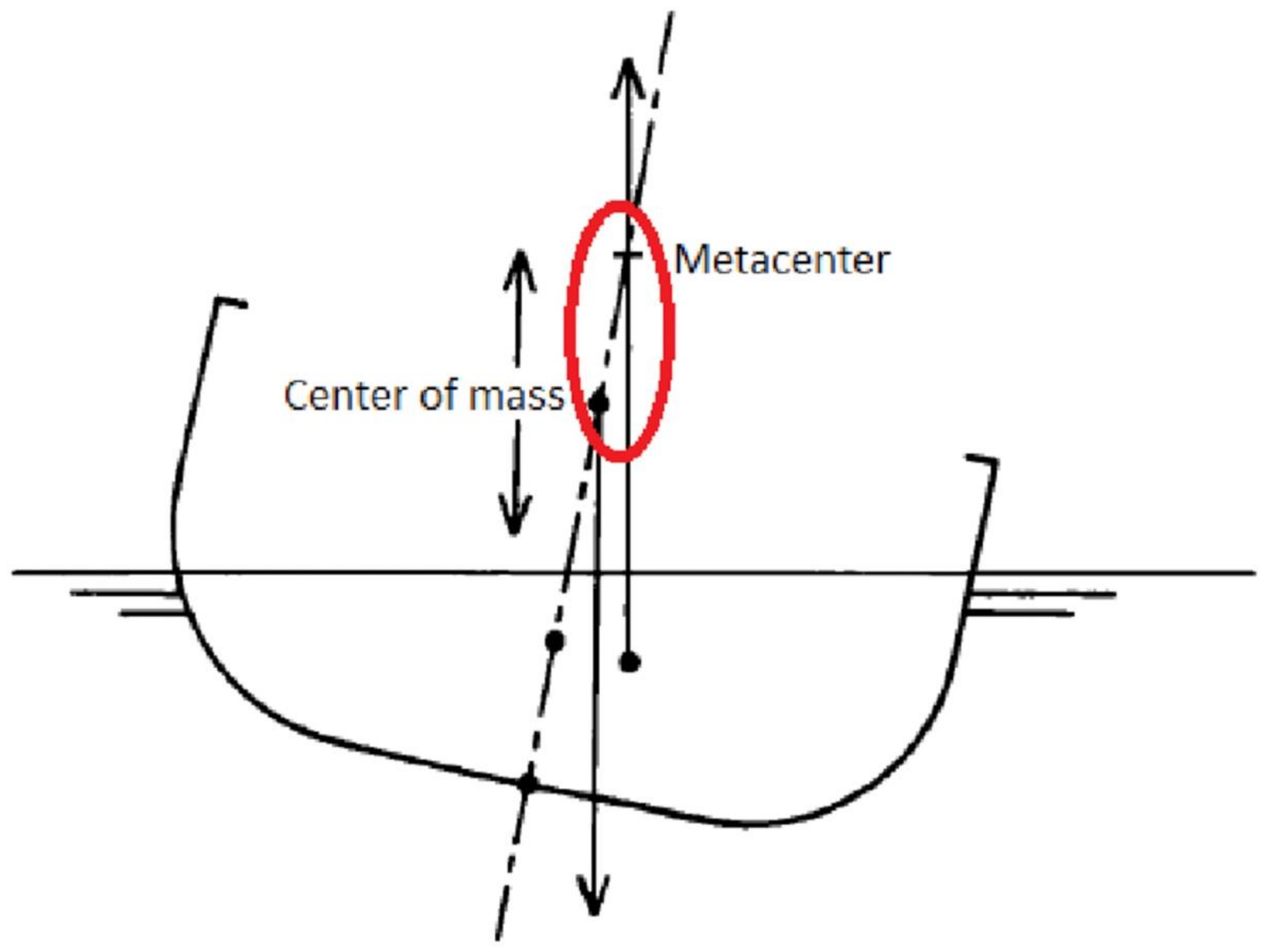

Figure 1: Schematic diagram depicting relationship between metacentre and centre of mass. The centre of mass can be moved up and down, with the distance between the two points (circled in red) affecting the stability of a ship. (McGrail, 1989: 355, fig. 1) 


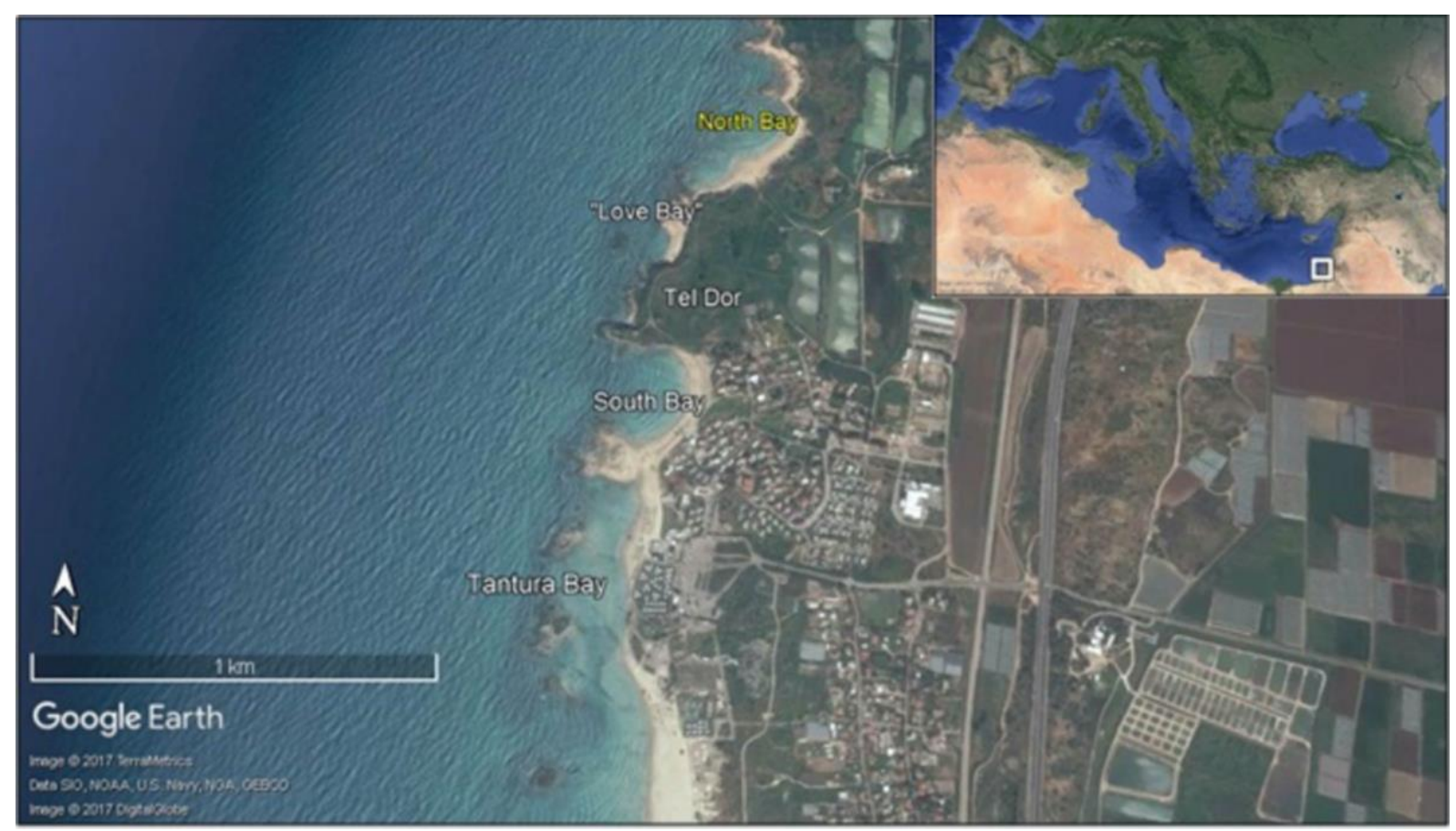

Figure 2: Map indicating location of the North Bay of Tel Dor, Israel. (Holdeman, 2017: 1, fig. 1.1)

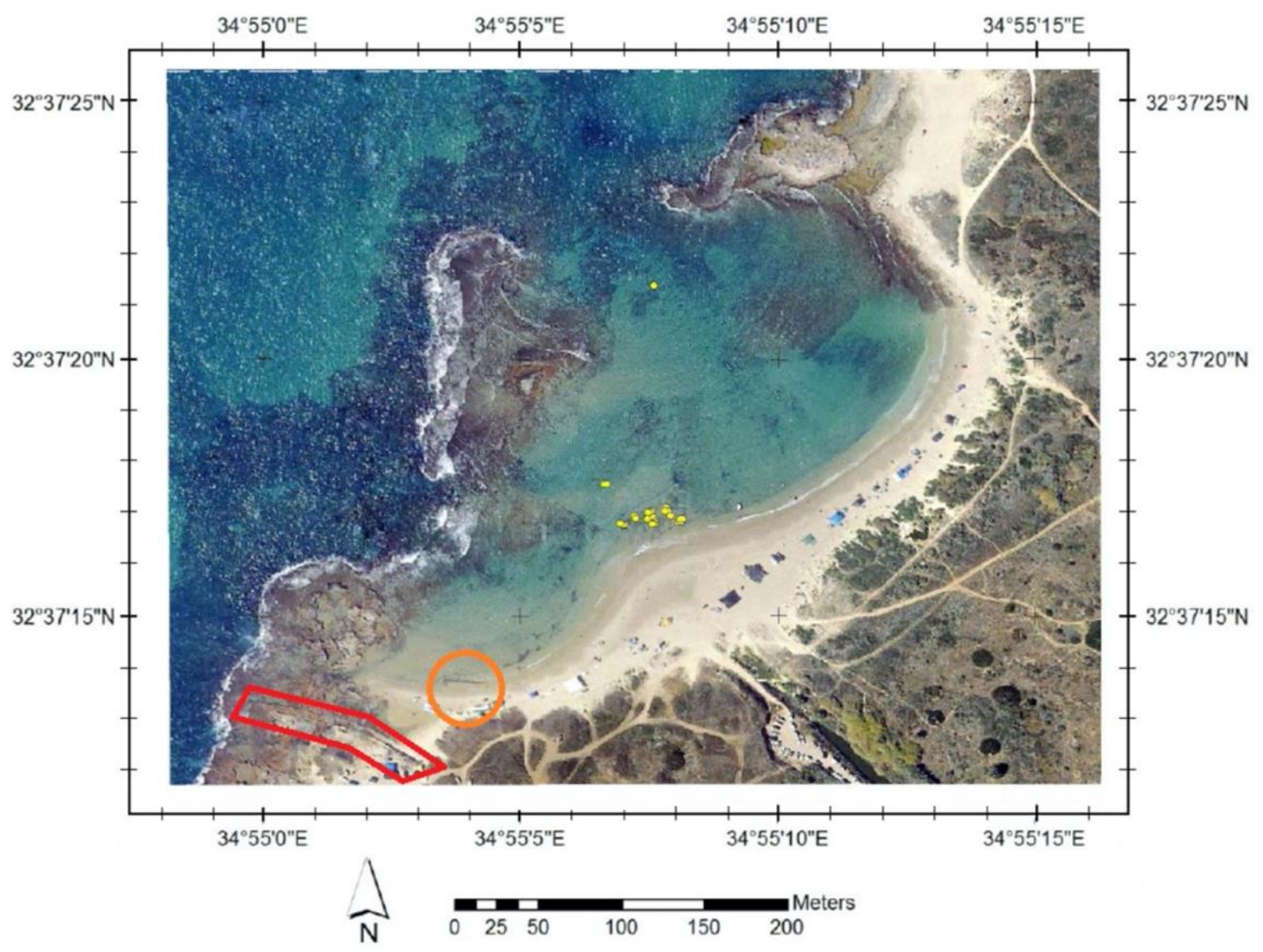

Figure 3: Map of architectural structures in the southern part of the North Bay of Tel Dor. Yellow dots indicate Raban's dozen columns. Most recent flushing channel is indicated by the red rectangle. The most visible wall in aerial view of Raban's rectangular structure is circled in orange. (Shalev, 2015: 41, fig. 4-2) 


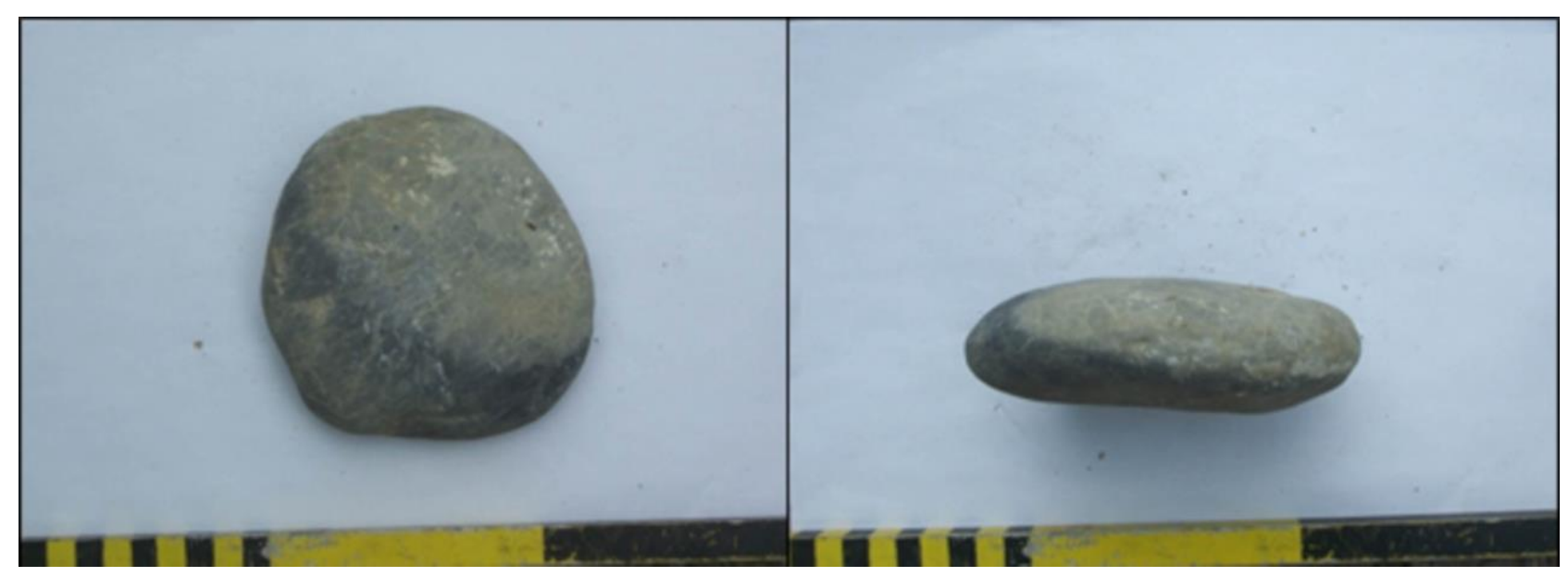

Figure 4: Example of stream-worn stone that is preferred shape of ballast stone. This is sample AH-9 from the study's assemblage. (Holdeman, 2017: 73, fig. 4.26)

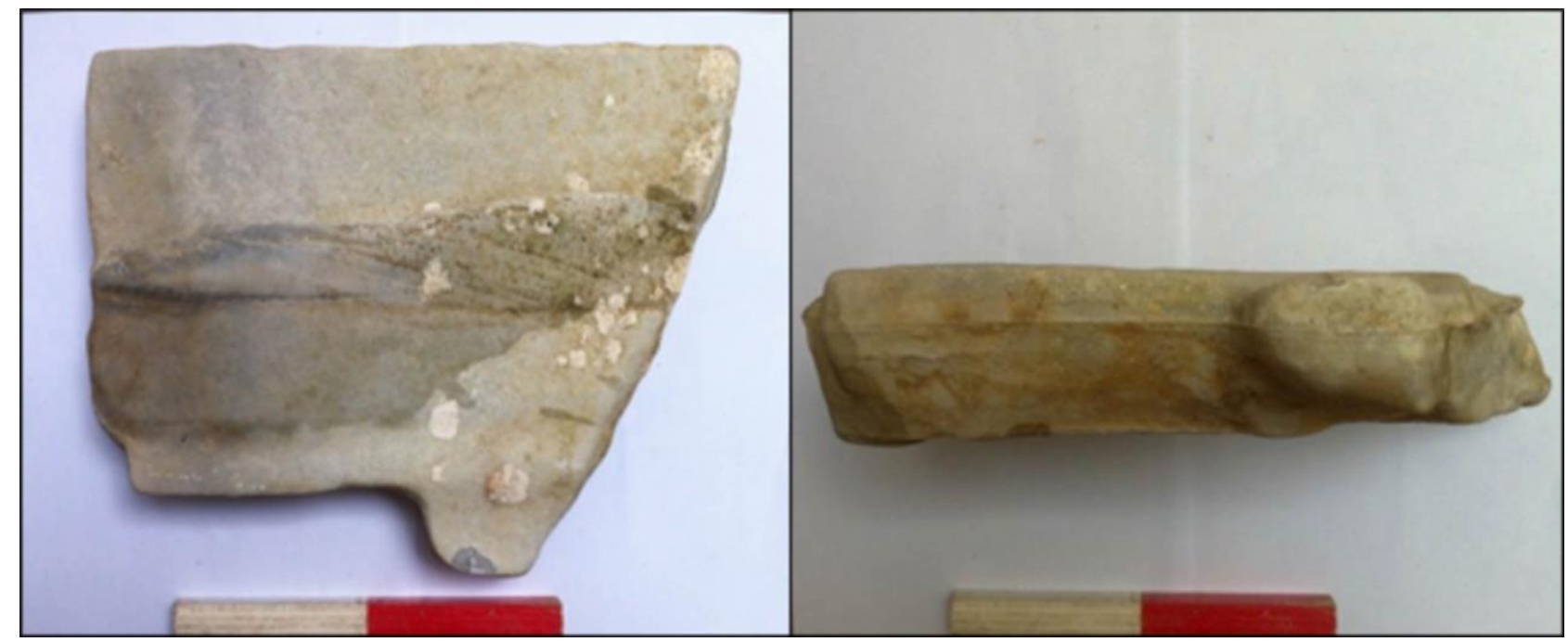

Figure 5: Example of architectural component used as a ballast stone. This is sample AH-37 from the study's assemblage. (Holdeman, 2017: 161, fig. 4.110) 


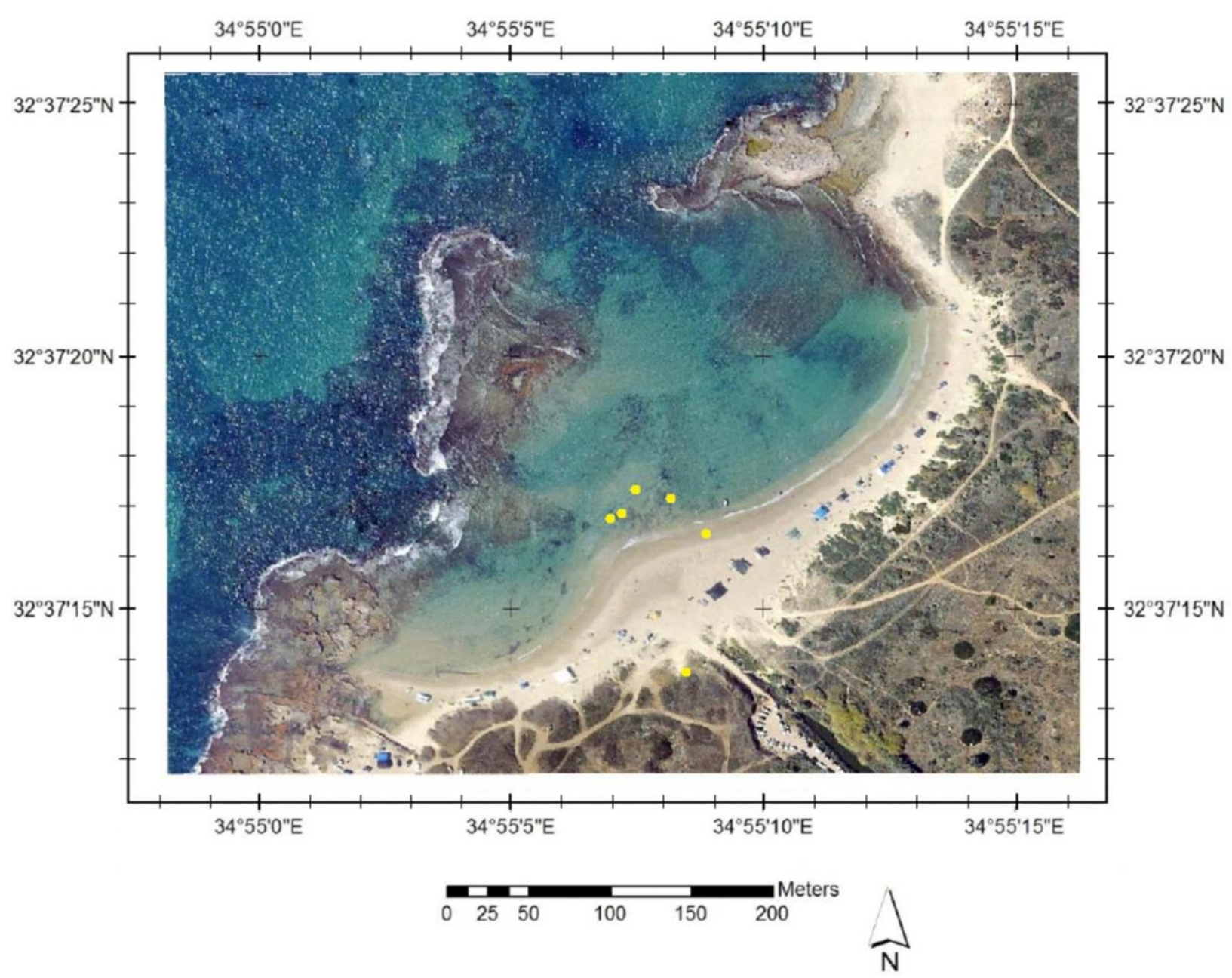

Figure 6: Points in the North Bay of Tel Dor for collection of ballast stones for this study. (Holdeman, 2017: 34, fig. 3.1) 


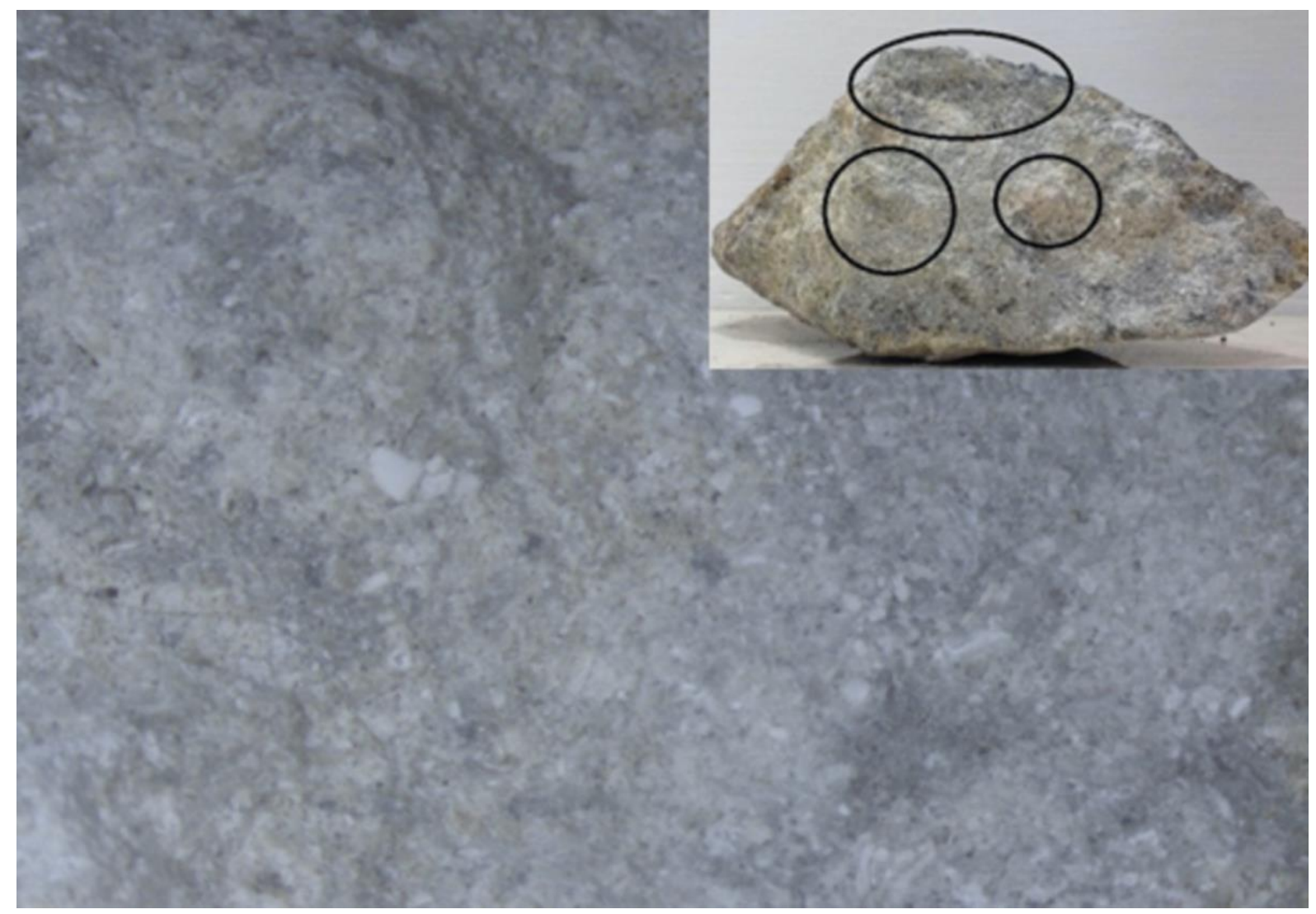

Figure 7: Example of macroscopic analysis done on this study's assemblage. The sample shown here is AH-1 and shows the interior to be composed of coarse sand that is grey, light grey, pale yellow, and white, with the white components resembling shell fragments. The inset shows the overall interior of the sample, while the main photo shows a close-up on the course sands and shell fragments. (Holdeman, 2017: 44, fig. 4.1 and 4.2)

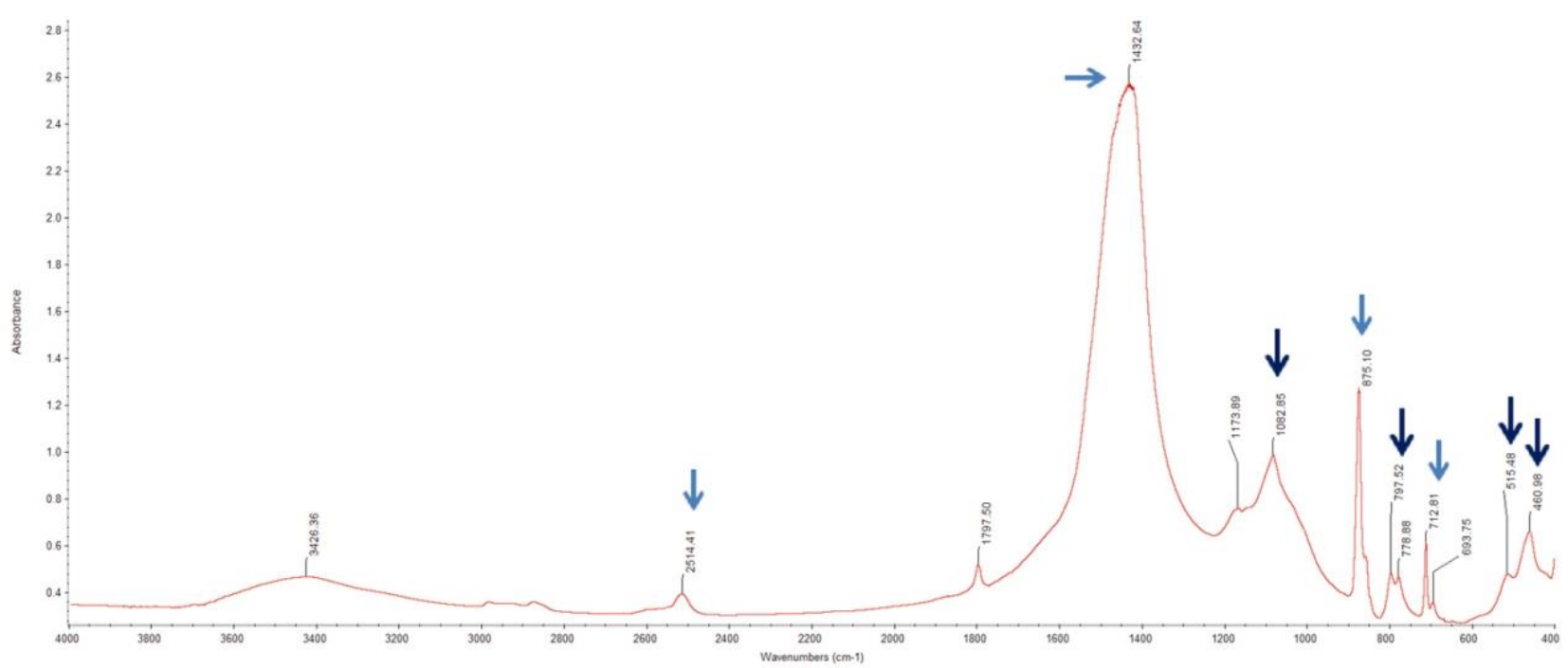

Figure 8: Spectra result from Fourier Transform Infrared (FTIR) analysis used on this study's assemblage for sample AH-1. The major peak of the whole spectra (ca. $1420 \mathrm{~cm}-1$, shown with light blue arrows) show a 
calcite dominance accompanied by quartz (major peak at ca. $1085 \mathrm{~cm} \mathrm{-1}$, shown by dark blue arrows).

(Holdeman, 2017: 46, fig. 4.3)
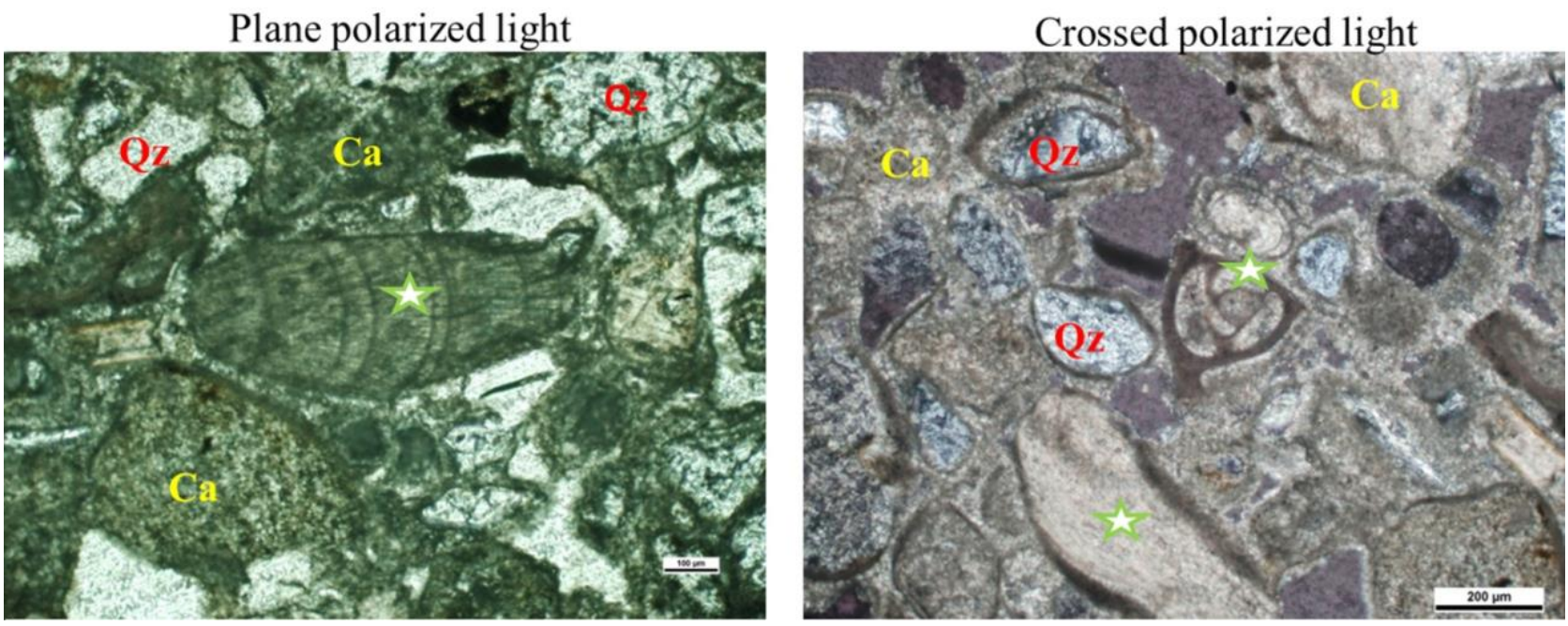

Figure 9: Results of petrographic analysis done on the study's assemblage for sample AH-1. The images show calcite $(\mathrm{Ca})$, quartz $(\mathrm{Qz})$, and shells and forminifera (starred) visible in both polarized and crossed polarized light. (Holdeman, 2017: 47-48, fig. 4.4)

\section{Tables}

Table 1: List of geological maps and resources used to identify coastal outcrops of the eastern Mediterranean as possible origins of ballast stones examined in this study.

\begin{tabular}{|l|l|}
\hline Geographic Region & Geological resource \\
\hline Israel & $\begin{array}{l}\text { Singer, 1967 } \\
\text { Frechen et al, 2004 } \\
\text { Hirsch, 2005 } \\
\text { Rosenfeld and Hirsch, 2005 }\end{array}$ \\
\hline Cyprus & $\begin{array}{l}\text { Geological Survey Department, Cyprus, 1979 } \\
\text { Bragin } \text { et al, 2005 } \\
\text { Krasheninnikov and Kaleda, 2005 } \\
\text { Portnyagin, 2005 } \\
\text { Silantyev and Krasheninnikov, 2005 } \\
\text { Silantyev et al, 2005 } \\
\text { Sillantyev, 2005a,b } \\
\text { Ertek } \text { et al, 2008 } \\
\text { McCay and Robertson, 2012 }\end{array}$ \\
\hline Turkey & $\begin{array}{l}\text { Pinar-Erdem, 1974: 119-123 } \\
\text { Brinkman, 1976 }\end{array}$ \\
\hline
\end{tabular}




\begin{tabular}{|c|c|}
\hline & $\begin{array}{l}\text { Bozkurt and Oberhänsli, } 2001 \\
\text { General Directorate of Mineral Research and Exploration, } 1989\end{array}$ \\
\hline Syria/Lebanon & $\begin{array}{l}\text { Beydoun, } 1977 \\
\text { Brew et al, } 2001 \\
\text { Al-Riyami et al, } 2002 \\
\text { Chan, } 2004 \\
\text { Ministry of Petroleum and Mineral Resources S.A.R., } 1986 \\
\text { Krashenionnikov, 2005a,b c } \\
\text { Ma et al, } 2011\end{array}$ \\
\hline Levant & Gvitrtzman, 2010 \\
\hline
\end{tabular}

Table 2: List of possible origins for each identified rock type. White rows are sedimetary rocks, light grey rows are igneous rocks, and dark grey rows are metamorphic rocks. (Holdeman, 2017: 163-164: Table 5.1)

\begin{tabular}{|c|c|c|}
\hline Rock Type & Sample & Coastal Areas Containing Rock Type \\
\hline Beach rock & $\begin{array}{l}\text { AH-1, AH-4, AH-6, } \\
\text { AH-17, AH-24 }\end{array}$ & $\begin{array}{l}\text { Rock type found throughout the eastern } \\
\text { Mediterranean coast }\end{array}$ \\
\hline Limestone & $\begin{array}{l}\mathrm{AH}-2, \mathrm{AH}-13, \mathrm{AH}- \\
16, \mathrm{AH}-23\end{array}$ & $\begin{array}{l}\text { Rock type found throughout the eastern } \\
\text { Mediterranean coast }\end{array}$ \\
\hline Chalk & AH-8 & $\begin{array}{l}\text { Israel, northern } \\
\text { Lebanon, southern }\end{array}$ \\
\hline Chert & $\mathrm{AH}-7, \mathrm{AH}-25$ & $\begin{array}{l}\text { Rock type found throughout the eastern } \\
\text { Mediterranean coast }\end{array}$ \\
\hline Dolomite & $\begin{array}{l}\text { AH-3, AH-10, AH- } \\
\text { 11, AH-20, AH-22, } \\
\text { AH-27 }\end{array}$ & $\begin{array}{l}\text { Rock type found throughout the eastern } \\
\text { Mediterranean coast }\end{array}$ \\
\hline $\begin{array}{l}\text { Conglomerate/ } \\
\text { Breccia }\end{array}$ & AH-14 & $\begin{array}{l}\text { Rock type found throughout the eastern } \\
\text { Mediterranean coast }\end{array}$ \\
\hline Microgabbro & AH-5, AH-19, AH-29 & $\begin{array}{l}\text { Cyprus, Troodos Ophiolite Complex } \\
\text { Turkey, southwestern } \\
\text { Syria, northern }\end{array}$ \\
\hline Pegmatitic quartz & AH-18 & $\begin{array}{l}\text { Egypt, Nile Valley } \\
\text { Egypt, Aswan }\end{array}$ \\
\hline $\begin{array}{ll}\text { Sandstone } & \text { (slightly } \\
\text { metamorphosed) } & \end{array}$ & $\mathrm{AH}-30$ & Cyprus, Mamonia Complex \\
\hline $\begin{array}{l}\text { Low grade marble (without } \\
\text { recrystallization) }\end{array}$ & AH-9 & Cyprus, Mamonia Complex \\
\hline
\end{tabular}




\begin{tabular}{|c|c|c|}
\hline & $\mathrm{AH}-34$ & Cyprus, Kyrenia Ridge \\
\hline $\begin{array}{l}\text { Low grade marble (with } \\
\text { recrystallization) }\end{array}$ & AH-28 & Cyprus, Kyrenia Ridge \\
\hline Dolomite marble & $\mathrm{AH}-10$ & Syria, Bassit-Baer Massif \\
\hline Quartzite & Ah-21 & $\begin{array}{l}\text { Cyprus, Mamonia Complex } \\
\text { Turkey, Menderes Massif }\end{array}$ \\
\hline Purple quartzite & $\mathrm{AH}-32$ & Syria, Palmyrides \\
\hline $\begin{array}{l}\text { Tonalite/quartz diorite } \\
\text { gneiss }\end{array}$ & $\mathrm{AH}-12$ & $\begin{array}{l}\text { Turkey, Marmara Island } \\
\text { Turkey, Menderes Massif } \\
\text { Egypt, Mon Claudius quarry }\end{array}$ \\
\hline White marble & $\mathrm{AH}-31$ & $\begin{array}{l}\text { Aegean Island, Thasos } \\
\text { Aegean Island, Paros } \\
\text { Aegean Island, Egeo } \\
\text { Aegean Island, Delos } \\
\text { Greece, Abdera } \\
\text { Turkey, Menderes Massif } \\
\text { Turkey, Marmara Island }\end{array}$ \\
\hline Grey-blue marble & AH-33, AH-37 & $\begin{array}{l}\text { Turkey, Menderes Massif } \\
\text { Crete, Ntikali } \\
\text { Italy, Carrara } \\
\text { Aegean Island, Egeo }\end{array}$ \\
\hline Brecciated marble & AH-36 & Aegean Island, Skyphos \\
\hline
\end{tabular}

